\title{
Fiscal and Monetary Policy
}

Federal Reserve Bank of San Francisco, Fourth Floor

March 4 - 5, 2005

\section{AGENDA}

\section{Friday, March 4}

Morning Session Chair: John Williams, Federal Reserve Bank of San Francisco

8:10 A.M. Continental Breakfast

8:50 A.M. Welcoming Remarks:

Janet Yellen, Federal Reserve Bank of San Francisco

9:00 A.M. Mitsuru Iwamura, Waseda University

Takeshi Kudo, Hitotsubashi University

Tsutomu Watanabe, Hitotsubashi University

Monetary and Fiscal Policy in a Liquidity Trap: The Japanese

Experience 1999-2004

Discussants: Laurence Ball, Johns Hopkins University

Marvin Goodfriend, Federal Reserve Bank of Richmond

10:30 A.M. Break

11:00 A.M. Jordi Galí, Universitat Pompeu Fabra

Tommaso Monacelli, Università Bocconi

Optimal Fiscal Policy in a Monetary Union

Discussants: Maurice Obstfeld, University of California, Berkeley

Carl Walsh, University of California, Santa Cruz

12:30 P.M. Lunch - Market Street Dining Room, Fourth Floor

Afternoon Session Chair: Richard Dennis, Federal Reserve Bank of San Francisco

2:00 P.M. William Brock, University of Wisconson

Steven Durlauf, University of Wisconsin

Kenneth West, University of Wisconsin

Model Uncertainty and Policy Evaluation: Some Theory and Empirics

Discussants: Lars Hansen, University of Chicago

Christopher Sims, Princeton University 
3:30 P.M. Break

4:00 P.M. Roberto Perotti, Università Bocconi

Estimating the Effects of Fiscal Policy in OECD Countries

Discussants: Alan Auerbach, University of California, Berkeley Valerie Ramey, University of California, San Diego

5:30 P.M. Reception - West Market Street Lounge, Fourth Floor

6:30 P.M. Dinner - Market Street Dining Room, Fourth Floor

Introduction: Janet Yellen, Federal Reserve Bank of San Francisco Speaker: Douglas Holtz-Eakin, Congressional Budget Office

\section{Saturday, March 5}

Morning Session Chair: Glenn Rudebusch, Federal Reserve Bank of San Francisco

8:00 A.M. Continental Breakfast

8:45 A.M. Jess Benhabib, New York University

Stefano Eusepi, Federal Reserve Bank of New York

The Design of Monetary and Fiscal Policy: A Global Perspective

Discussants: George Evans, University of Oregon

John Leahy, New York University

10:15 A.M. Break

10:30 A.M. Andrew Ang, Columbia University Sen Dong, Columbia University

Monika Piazzesi, University of Chicago

No-Arbitrage Taylor Rules

Discussants: Andrew Levin, Federal Reserve Board

Thomas Philippon, New York University

12:00 P.M. Lunch 